\title{
THE EFFECT OF PRODUCT QUALITY AND PRICE ON SALES IN “SAPARDI” BAKSO IN GAYUNGAN JEMUR
}

\author{
Nindya Kartika Kusmayati, Zahro Aldieniyah \\ STIE Mahardhika Surabaya
}

\begin{abstract}
This research is a quantitative study that aims to answer the question of whether product quality and price affect the sales level of the "SAPARDI" meatballs in Jemur Gayungan street. This research uses the quantitative method with a customer satisfaction survey approach. The sampling technique in this study was purposive sampling, with 78 respondents. Data collection technique used questionnaires and were processed using SPSS statistics 16 . The results showed that the quality of the product had a partially positive but not significant effect, meaning that it had an effect but it was very small and it was necessary to make creative ideas for its products. Price has a positive and significant effect, meaning that price is one of the reasons customers buy Sapardi meatballs. There is a simultaneous influence between product quality and price variables on the Sales Level of the "SAPARDI" Meatballs in Jemur Gayungan but the effect is not too significant, so it is necessary to do further research using other variables.
\end{abstract}

Keywords: product quality, price, sales

\section{A. PRELIMINARY}

Competition is getting tougher in the business world, especially due to the increasing the number of MSMEs in Indonesia. Currently, one of rapidly growing businesses is the culinary field, with a variety of food innovations served, affordable prices to all levels of society, and service quality that is not inferior to the middle-class restaurant business. Small entrepreneurs, especially in the culinary field, are demanded to be able to design and innovate marketing strategies so as to be able to create, maintain, and increase customer satisfaction, which will gain the trust of consumers.

\footnotetext{
"Corresponding Author.

e-mail: Nindya.Kusmayati@stiemahardhika.ac.id
} 
In the increasingly fierce competition in the demanding business world, micro entrepreneurs have to implement efficiency and effectiveness in their business, as well as mobility from one place to another in order to increase sales turnover. Therefore, innovation is absolutely necessary to meet the tastes of consumers if micro businesses don't want to lose customers and the growing demand for its products. For micro-level businesses, price is one of the main factors making this product enjoyable by all groups.

Facing the intense competition in the field of marketing, consumer demands for affordable prices and quality product must be answered. The importance of pricing and product quality is an advantage for micro entrepreneurs in increasing sales. Mr. Sapardi, who had a business selling meatballs from 1990 to 2019, was initially very in demand; but in the last year began to experience a decline in sales. However, he did not know the exact cause of the decline in sales of the meatball. On this basis, the researchers tried to look for problems and to identify them by conducting a customer satisfaction survey of the sale of Mr. Sapardi's meatballs located on Jalan Jemur Gayungan I Surabaya.

\section{B. THEORETICAL BASIS}

\section{Product quality}

According to Kotler and Armstrong (2007) in Rafikhein, N., and Ahiy, D., 2018 , product quality is the ability of a product to perform its function. These abilities include the durability of a product, accuracy, reliability, ease of operation and repair, and other valuable attributes of the product as a whole. According to Kotler and Armstrong (2010) in Rafikhein, N., and Ahiy, D., 2018, product quality is a characteristic of a product or service that provides the ability to satisfy or meet customer needs. According to Tjiptono (2008), classifying products can be done with a variety of perspectives, based on whether or not they are present, and products can be classified into two categories, namely goods and services. Judging from the aspects of endurance there are two kinds, namely: 1 . goods that are not durable; and 2. durable goods. Non-durable goods are tangible goods which are consumed in one use or several times of use only. Durable goods are tangible items that can last a long time with many times of usage. 
Product Quality Indicators According to Sviokla in Lupioadi (2013) in Rafikhein, N., and Ahiy, D., 2018 quality has eight dimensions of measurement consisting of various aspects. (1) Performance refers to aspects of individual performance, brand, and attributes that can be measured. (2) Durability means how long a product's life will last and before it must be replaced. (3) Compliance with specifications is the extent to which the basic operating characteristics of a product meets certain specifications from consumers and how there are no defects found in the product. (4) Product privileges is in the form of additional products from core products that can add value to the product. (5) Reliability relates to the possibility of a product experiencing a state of non-functioning in a period. (6) Service capability is the ability to be serviced. 158 JMK (Journal of Management and Entrepreneurship) 3 (3) 2018, 155-165 in speed, usability, competence and ease of products to be improved. 7. Esthetics is related to how the product's appearance can be perceived from the taste, smell, appearance, and shape of a product. Kotler (2011: 49), explained that the quality of the product is the overall characteristics and if a product or service have the ability to satisfy expressed/implied needs.

\section{Price}

Price is the amount of money that must be paid to get the right to use the product. Economics often assumes that lower prices for the same product will generate more sales than higher prices. However, prices sometimes serve as a signal of quality. Products that are too low may be considered of low quality" (Hawkins and Mothersbaugh, 2010) in Ulfa Isabella1, F. Danardana Murwani, 2016.

Traditionally, price is one of the main components in the decision-making process to buy a product. In this study, the price is defined as the ability of a person to assess an item with a unit of measurement in Rupiahs to be able to buy the products offered. According to Germany in Tjiptono (2009: 178), the term price can be simply interpreted as the amount of money (monetary units) and/ or other aspects (non-monetary) that contain certain utilities/uses needed to obtain a service. Utility is an attribute or factor that has the potential to satisfy certain needs and desires. Price also means the amount of money consumers must 
pay to get a product. Meanwhile, according to Kotler and Armstrong (2001), price is the amount of value charged for a product.

According to Kotler and Armstrong as translated by Sabran (2013: 52) in Rifda Fitrianty 2020, there are three indicators for price, namely affordable prices, price conformity with product quality, and price according to ability or price competitiveness. Three price indicators, namely: (1) affordability of consumer to pay the prices set by businesses. Usually there are several types of products in one brand with different pricing, from the cheapest to the most expensive. With prices set based on consumers, many would buy the products; (2) the suitability of the price with the quality of the product. Price is often used as an indicator of quality for consumers as people often choose higher price between two goods because they see a difference in quality. With higher prices, people tend to assume that the quality is also better. Price is in accordance with the ability or price competitiveness; (3) consumers often compare product prices with other products, in this case the expensive price of a product is highly considered by consumers when they will buy products.

\section{Sales}

According to Tjiptono (2008: 215) in Cornelia Dumarya Manik, 2015, "sale is the transfer or transfer of ownership rights to goods or services from one party to another accompanied by the delivery of compensation from the recipient of the goods or services in return for the handover". Sales is the main activity carried out by almost all business entities, because the proceeds from the sales are part of the survival of the company itself. Sales is a tool that generates income in the form of cash receipts and trade receivables. Therefore, all companies must be clever in carrying out sales activities of their products and also needs to consider sales targets.

Freddy Rangkuti stated (2009: 57), "sales volume is the achievement of sales that are expressed quantitatively in terms of physical or volume or unit of a product". The ups and downs in sales can be seen from the units, kilograms, and liters of the product sales. From the description above, the authors conclude that sales volume is the overall result of the sale of an item obtained by the business owner or company within a certain period. 
Basu Swastha (2008: 406) stated that "sales activities are influenced by several factors, namely Conditions and the ability of Sellers". Sellers must be able to convince buyers to successfully sell their products and achieve the expected sales goals". Market Conditions, Basu Swastha (2008: 138) stated "Market, as a group of buyers or parties who are targeted in sales". Market condition factors that need to be considered are the consumer market, consisting of final consumers who use ready-made products without having to process them again. For example are snack products, clothing, and so forth. Buyer Groups and Business actors must recognize groups of buyers. The seller should make observations on buyers in the consumer market, so the products created are right on target and in accordance with the buyers. Purchasing Power, Sellers should know the conditions or purchasing power of the buyers, so that the sellers do not experience failure when selling its products. This is done with the aim that the product can be bought by consumers at affordable prices. Desires and Needs, Business actors must be able to know or predict the needs and desires of consumers so that products made can successfully achieve the expected goals and not become a failed product.

\section{RESEARCH PURPOSES}

This research was conducted with the aim to find out and analyze the partial and simultaneous effect of quality of products and prices on the sale of Sapardi meatballs

\section{CONCEPTUAL FRAMEWORK}

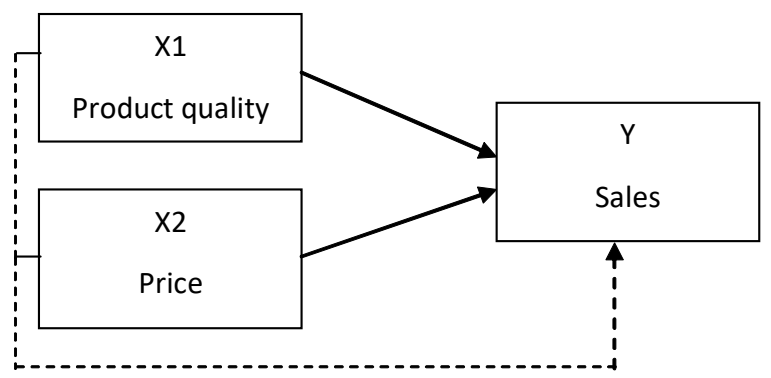

Figure 1 Conceptual framework 


\section{E. RESEARCH METHODS}

This research used the quantitative survey method approach. The population is Pak Sapardi's meatball customers who have bought Pak Sapardi's meatball more than 3 times with an unknown population, so the sampling technique uses Roscoe in the book Research Methods for Business (1982: 253). Sugiyono (2017: 105) gave suggestions about sample sizes for the research as follows: the size of the sample that is feasible in research is between 30 to 500 . If the study will conduct multivariate analysis (correlation or multiple regression, for example), then the number of sample members is at least 10 times the number of variables studied. There are 3 research variables (independent + dependent) and then the number of sample members $=10 \times 3=30$. The researcher took a sample of 78 respondents to be given a questionnaire as primary data. Researchers used purposive sampling as a sampling technique with certain considerations. The analysis included the validity test, reliability test, normality test, classic assumption test, and data analysis using multiple linear regression with SPSS16 Software.

\section{F. RESULTS AND DISCUSSION}

In this study, respondents who were involved and were eligible for further analysis were 78 respondents. Next, the researchers used multiple linear regression with the SPSS 16 computer program for Windows. Before testing the hypothesis, a validity and reliability test is performed, and a classic assumption test of the data is analyzed.

\section{Correlations}

\begin{tabular}{|ll|r|r|r|r|r|r|r|r|}
\hline & $\begin{array}{c}\text { Product } \\
\text { Quality } \\
1\end{array}$ & $\begin{array}{c}\text { Product } \\
\text { Quality } \\
2\end{array}$ & $\begin{array}{r}\text { Product } \\
\text { Quality } \\
3\end{array}$ & $\begin{array}{r}\text { Product } \\
\text { Quality } \\
4\end{array}$ & $\begin{array}{c}\text { Product } \\
\text { Quality } \\
5\end{array}$ & $\begin{array}{r}\text { Product } \\
\text { Quality } \\
6\end{array}$ & $\begin{array}{r}\text { Product } \\
\text { Quality } \\
7\end{array}$ & $\begin{array}{r}\text { Product } \\
\text { Quality }\end{array}$ \\
\hline $\begin{array}{l}\text { Product } \\
\text { Quality 1 }\end{array}$ & $\begin{array}{l}\text { Pearson } \\
\text { Correlation }\end{array}$ & 1 &,- 045 & 220 & -.070 & .078 & $.373 * *$ & 109 & $.489 * *$ \\
& Sig. (2-tailed) & & .697 & .053 & .545 & .999 & .001 & .344 & .000 \\
$\mathrm{~N}$ & 78 & 78 & 78 & 78 & 78 & 78 & 78 & 78 \\
\hline
\end{tabular}


Nindya Kartika Kusmayati, Zahro Aldieniyah / The Effect of Product Quality and Price on Sales in "Sapardi" Bakso in Gayungan Jemur

\begin{tabular}{|c|c|c|c|c|c|c|c|c|c|}
\hline \multirow[t]{3}{*}{\begin{tabular}{|l} 
Product \\
Quality 2
\end{tabular}} & $\begin{array}{l}\text { Pearson } \\
\text { Correlation }\end{array}$ & & 1 & .029 & $.252 *$ & .196 & .021 & $.244 *$ & $.520 *$ \\
\hline & Sig. (2-tailed) & .697 & & .803 & .026 & .86 & .855 & .032 & .000 \\
\hline & $\mathrm{N}$ & 78 & 78 & 78 & 78 & 78 & 78 & 78 & 78 \\
\hline \multirow[t]{3}{*}{\begin{tabular}{|l} 
Product \\
Quality 3
\end{tabular}} & $\begin{array}{l}\text { Pearson } \\
\text { Correlation }\end{array}$ & 220 & .029 & 1 & .94 & 171. & 220 & .103 & $.545 *$ \\
\hline & Sig. (2-tailed) & .053 & .803 & & .414 & .134 & .053 & 368 & .000 \\
\hline & $\mathrm{N}$ & 78 & 78 & 78 & 78 & 78 & 78 & 78 & 78 \\
\hline \multirow[t]{3}{*}{\begin{tabular}{|l} 
Product \\
Quality 4
\end{tabular}} & $\begin{array}{l}\text { Pearson } \\
\text { Correlation }\end{array}$ & & $.252 *$ & .94 & 1 & $.265 *$ & -.206 & .057 & \\
\hline & Sig. (2-tailed) & .545 & .026 & .414 & & .019 & .070 & .619 & .000 \\
\hline & $\mathrm{N}$ & 78 & 78 & 78 & 78 & 78 & 78 & 78 & 78 \\
\hline \multirow[t]{3}{*}{$\begin{array}{l}\text { Product } \\
\text { Quality } 5\end{array}$} & $\begin{array}{l}\text { Pearson } \\
\text { Correlation }\end{array}$ & .078 & .196 & 171. & $.265 *$ & 1 & $-.246 *$ & .99 & \\
\hline & Sig. (2-tailed) & .999 & .86 & .134 & .019 & & .030 & .081 & .000 \\
\hline & $\mathrm{N}$ & 78 & 78 & 78 & 78 & 78 & 78 & 78 & 78 \\
\hline \multirow[t]{3}{*}{$\begin{array}{l}\text { Product } \\
\text { Quality } 6\end{array}$} & $\begin{array}{l}\text { Pearson } \\
\text { Correlation }\end{array}$ & & .021 & 220 & -.206 & & 1 & .013 & \\
\hline & Sig. (2-tailed) & .001 & .855 & .053 & .070 & .030 & & .912 & .003 \\
\hline & $\mathrm{N}$ & 78 & 78 & 78 & 78 & 78 & 78 & 78 & 78 \\
\hline \multirow[t]{3}{*}{$\begin{array}{l}\text { Product } \\
\text { Quality } 7\end{array}$} & $\begin{array}{l}\text { Pearson } \\
\text { Correlation }\end{array}$ & 109 & $.244 *$ & 103 & .057. & .99 & .013 & 1 & $.505 *$ \\
\hline & Sig. (2-tailed) & .344 & .032 & 368 & .619 & .081 & .912 & & .000 \\
\hline & $\mathrm{N}$ & 78 & 78 & 78 & 78 & 78 & 78 & 78 & 78 \\
\hline \multirow[t]{3}{*}{$\begin{array}{l}\text { Product } \\
\text { Quality } 8\end{array}$} & $\begin{array}{l}\text { Pearson } \\
\text { Correlation }\end{array}$ & $.489 * *$ & $.520 * *$ & $.545 * *$ & $.430 * *$ & $.516 * *$ & $.334 * *$ & $.505 *$ & 1 \\
\hline & Sig. (2-tailed) & .000 & .000 & .000 & .000 & .000 & .003 & .000 & \\
\hline & $\mathrm{N}$ & 78 & 78 & 78 & 78 & 78 & 78 & 78 & 78 \\
\hline
\end{tabular}

$* *$. Correlation is significant at the 0.01 level (2-tailed).

* Correlation is significant at the 0.05 level (2-tailed).

\section{Correlations}

\begin{tabular}{|rl|r|r|r|r|}
\hline & Price 1 & Price 2 & Price 3 & \multicolumn{1}{c|}{ Price } \\
\hline Price 1 & Pearson Correlation & 1 & .201 & .077 & $.693 * \%$ \\
& Sig. (2-tailed) & & .078 & .501 & .000 \\
$\mathrm{~N}$ & 78 & 78 & 78 & 78 \\
\hline
\end{tabular}


Review of Management and Entrepreneurship

Volume 04, Number 02, October 2020

\begin{tabular}{|ll|r|r|r|r|}
\hline Price 2 & Pearson Correlation & .201 & 1 & $.296 * *$ & $.694 * *$ \\
& Sig. (2-tailed) & .078 & & .008 & .000 \\
& $\mathrm{~N}$ & 78 & 78 & 78 & 78 \\
\hline Price 3 & Pearson Correlation & .077 & $.296 * *$ & 1 & $.643 * *$ \\
& Sig. (2-tailed) & .501 & .008 & & .000 \\
& $\mathrm{~N}$ & 78 & 78 & 78 & 78 \\
\hline Price & Pearson Correlation & $.693 * *$ & $.694 * *$ & $.643 * *$ & 1 \\
& Sig. (2-tailed) & .000 & .000 & .000 & \\
& $\mathrm{~N}$ & 78 & 78 & 78 & 78 \\
\hline
\end{tabular}

**. Correlation is significant at the 0.01 level (2-tailed).

\section{Correlations}

\begin{tabular}{|c|c|c|c|c|c|c|}
\hline & & Sale 1 & Sale 2 & Sale 3 & Sale 4 & Sale \\
\hline \multirow[t]{3}{*}{ Sale 1} & Pearson Correlation & 1 & $.380 * *$ & $.541 * *$ & $.408 * *$ & $.772 * *$ \\
\hline & Sig. (2-tailed) & & .001 & .000 & .000 & .000 \\
\hline & $\mathrm{N}$ & 78 & 78 & 78 & 78 & 78 \\
\hline \multirow[t]{3}{*}{ Sale 2} & Pearson Correlation & $.380 * *$ & 1 & $.362 * *$ & $.255 *$ & $.641 * *$ \\
\hline & Sig. (2-tailed) & .001 & & .001 & .024 & .000 \\
\hline & $\mathrm{N}$ & 78 & 78 & 78 & 78 & 78 \\
\hline \multirow[t]{3}{*}{ Sale 3} & Pearson Correlation & $.541 * *$ & $.362 * *$ & 1 & $.549 * *$ & $.803 * *$ \\
\hline & Sig. (2-tailed) & .000 & .001 & & .000 & .000 \\
\hline & $\mathrm{N}$ & 78 & 78 & 78 & 78 & 78 \\
\hline \multirow[t]{3}{*}{ Sale 4} & Pearson Correlation & $.408 * *$ & $.255 *$ & $.549 * *$ & 1 & $.776 * *$ \\
\hline & Sig. (2-tailed) & .000 & .024 & .000 & & .000 \\
\hline & $\mathrm{N}$ & 78 & 78 & 78 & 78 & 78 \\
\hline \multirow[t]{3}{*}{ Sale } & Pearson Correlation & $.772 * *$ & $.641 * *$ & $.803 * *$ & $.776 * *$ & 1 \\
\hline & Sig. (2-tailed) & .000 & .000 & .000 & .000 & \\
\hline & $\mathrm{N}$ & 78 & 78 & 78 & 78 & 78 \\
\hline
\end{tabular}

$*$. Correlation is significant at the 0.01 level (2-tailed).

* Correlation is significant at the 0.05 level (2-tailed). 
Nindya Kartika Kusmayati, Zahro Aldieniyah / The Effect of Product Quality and Price on Sales in "Sapardi" Bakso in Gayungan Jemur

Table 2 Reliability Tests

\begin{tabular}{|c|c|c|}
\hline Variable & $\begin{array}{c}\text { Cronbach's Alpha if } \\
\text { Item Deleted }\end{array}$ & Information \\
\hline Product Quality & .678 & reliable \\
\hline Price & 0.755 & reliable \\
\hline Sale & 0.795 & reliable \\
\hline
\end{tabular}

Model Summaryb

\begin{tabular}{|l|r|r|r|r|r|r|r|r|r|r|}
\hline \multirow{2}{*}{ Model } & \multirow{2}{*}{$\mathrm{R}$} & \multirow{2}{*}{$\begin{array}{c}\mathrm{R} \\
\text { Square }\end{array}$} & $\begin{array}{c}\text { Adjusted R } \\
\text { Square }\end{array}$ & $\begin{array}{c}\text { Std. Error of } \\
\text { the Estimate }\end{array}$ & $\begin{array}{c}\text { R Square } \\
\text { Change }\end{array}$ & F Change & df1 & df2 & $\begin{array}{c}\text { Sig. F } \\
\text { Change }\end{array}$ & $\begin{array}{c}\text { Durbin- } \\
\text { Watson }\end{array}$ \\
\hline 1 & $.571 \mathrm{a}$ & .326 & .308 & 1.507 & .326 & 18.157 & 2 & 75 & .000 & 2,532 \\
\hline
\end{tabular}

a. Predictors: (Constant), Price, Product Quality

b. Dependent Variable: Sale

Coefficientsa

\begin{tabular}{|c|c|c|c|c|c|c|c|c|c|c|}
\hline \multirow{2}{*}{ Model } & \multicolumn{2}{|c|}{$\begin{array}{c}\text { Unstandardiz } \\
\text { ed } \\
\text { Coefficients }\end{array}$} & \multirow{2}{*}{\begin{tabular}{|c|}
$\begin{array}{c}\text { Standar } \\
\text { dized } \\
\text { Coeffici } \\
\text { ents }\end{array}$ \\
Beta
\end{tabular}} & \multirow{2}{*}{$\mathrm{t}$} & \multirow{2}{*}{ Sig. } & \multicolumn{3}{|c|}{ Correlations } & \multicolumn{2}{|c|}{$\begin{array}{l}\text { Collinearity } \\
\text { Statistics }\end{array}$} \\
\hline & B & $\begin{array}{l}\text { Std. } \\
\text { Error }\end{array}$ & & & & $\begin{array}{l}\text { Zero- } \\
\text { order }\end{array}$ & Partial & Part & Tolerance & VIF \\
\hline (Constant) & 4,300 & 1,201 & & 3,580 & .001 & & & & & \\
\hline $\begin{array}{l}\text { Product } \\
\text { Quality }\end{array}$ & .96 & .071 & .137 & 1,357 & .179 & .312 & .155 & .129 & .883 & 1,133 \\
\hline Price & .654 & .129 & .510 & 5,051 & .000 & .557 & .504 & 479 & .883 & 1,133 \\
\hline
\end{tabular}

a. Dependent Variable:

Sales

The results of the multiple linear regression analysis above can be notated according to the analysis of the regression equation model as follows:

$$
\mathrm{Y}=4,300+0.096 \mathrm{X} 1+0.654 \mathrm{X} 2
$$

From the equation above, it can be seen that the constant coefficient (a) of 4.300 means that if the quality of the product (X1) and price (X2) all have a value of 0 units, sales will increase by 4,300 units. Regression coefficient (b1) of (0.096) shows a positive relationship, meaning that if the product quality (X1) is increased by 1 unit then sales $(\mathrm{Y})$ will increase by 0.096 units assuming the 
value of the variable price (X2) is fixed or zero. Vice versa, if the product quality (X1) is reduced by 1 unit then sales (Y) will decrease by 0.096 units assuming the value of the variable price (X2) is fixed or zero. The regression coefficient (b2) of 0.654 indicates a positive relationship, meaning that if the price (X2) is increased by 1 unit then sales $(\mathrm{Y})$ will decrease by 0.654 units assuming the value of the product quality variable (X1) is fixed or zero.

From the multiple linear regression equation and the description above, it can be seen that the product quality variable (X1) has a positive effect on Sapardi meatball sales but is not significant. While the price variable (X2) has a positive and significant effect on Sapardi meatball sales.

$\mathrm{R}$ Square value shows the value of 0.326 or $32.6 \%$, which means that the independent variable in this study, namely product quality and price is able to explain the effect of $32.6 \%$ on the dependent variable (sales) and the rest is influenced by other variables not examined, for example service quality, location, purchasing decisions, media promotions, etc.

\section{G. CONCLUSION}

Based on the results of the study, the quality of the product partially had a positive but not significant effect, meaning that even though the quality of the Sapardi meatball product has an effect on sales, it is very small. Price has a positive and significant effect on Sapardi meatball sales. Simultaneously, the product quality and price have a significant effect of $32.6 \%$ while the rest are influenced by other variables.

\section{H. SUGGESTION}

Based on the results of data analysis and discussion, researchers provide suggestions to increase Sapardi meatball sales, among others as follows, "SAPARDI" meatballs in the Jemur Gayungan street must innovate in the creation of meatball products, ranging from taste, style, variety, and the attractiveness of Sapardi meatballs. If needed, the business can make a new variant such as meatballs with a variety of contents like cheese filled meatballs, quail eggs, mushroom, or spicy meatballs. In terms of shape, it can be round, square, large, or small. There can 
also be variations in taste from dumplings and fries, or there may be vegetable variants, for example cabbage, mustard greens, sprouts, etc. This way, customers have many choices and customers can be satisfied and will continue to buy and hence increases the number of customers.

Based on research in terms of price, it turns out that it still influences the increase in sales, meaning that the price of Sapardi meatballs is relatively cheap according to the customers and the price provides its own attraction to the increase in sales of Sapardi meatballs. Therefore, the relatively low prices must be maintained so that customers do not switch to other meatball sellers.

Based on the results of the study, it can also be shown that together the product quality and price influence sales by $32.6 \%$. This indicates that further research is still needed to find out other variables that have greater effect on sales.

\section{BIBLIOGRAPHY}

Frendy O. Mokalu, A.T. 2015. The Effect of Product Quality, Price and Distribution on the Sales Volume of Jordan Cv Bread. Emba Journal: Journal of Economic Research, Management, Business and Accounting, Vol. 3, No. 1.

Irawan, B.S. 2008. Modern Marketing Management.

Isabella1, U. \& Murwani, F. 2016. Effect of Quality and Price of Meatball on Consumer Purchase Decision. (The Third International Conference on Entrepreneurship).

Kotler, P.D. 2009. Marketing, Management 13th Edition Translation Taufik Amir. Kurnianto, W.M., Rosalina, S.S., \& Nurminingsih. Effect of Marketing Mix and Product Quality on Purchase Decision to the Special sb Packaging Beef Meatball through Brand Image and Purchase Intention, Vol. 6 (Issue 2 April, 2019), 86-96.

Manik, C.D. 2020. The Effect of Product Quality, Price and Promotion on Sales Level (Study in Serpong Garden Housing). CREATIVE Scientific Journal of Management Study Program at Pamulang University, Vol. 3, No. 1 (October 2015). 
Nasution, M.I., Prayogi, M.A., \& Nasution, S.M. 2017. The Influence of Product Quality. Promotion Against Sales in the Footwear Craft Micro Business in Medan Denai District, Vol. 7, No. 1.

Rachmasari, M., Setiawan, B.M., \& Santoso, S.I. 2019. Analysis of the Effect of Product Prices and Quality on Rubber Sales Volume of PT Perkebunan Nusantara IX Semarang. DOI 10.22219/agriecobis , Vol. 2, No. 2, 87-94. Rafikhein, N. \& Athiy, D. 2018. The Effect of Product Quality and Prices on Sales at UD Beski Jaya. JMK (Journal of Management and Entrepreneurship).

Rangkuti, F. 2009. Riset Pemasaran.

Rifda Fitrianty, S.M., Wildagdo, I.L., Kuswandi, M., \& Diah Ayu Sanggarwati, S.M. 2020. Orientation on Product Quality and Price Perception of Purchasing Decisions by Mediatiing the Buying Interest of Noodles (Chicken) Consumers in Indonesia, Volume 03 (Issue-03, pp. 53-60 March-2020). 